\title{
Foliar micromorphology and anatomy of Ugni molinae Turcz. (Myrtaceae), with particular reference to schizogenous secretory cavities
}

\author{
Hernan A Retamales ${ }^{1 *}$, Rosa Scherson ${ }^{2}$ and Tanya Scharaschkin ${ }^{1}$
}

\begin{abstract}
Background: Ugni molinae Turcz. is one of the most studied species of South American Myrtaceae due to its edible fruits and foliar medicinal compounds. However, there is no anatomical study of the leaves or secretory cavities. This paper seeks to describe the leaf micromorphology and anatomy of the species using standard protocols for light and scanning electron microscopy. Secretory cavities were anatomically characterized in young and mature leaves. Histochemical staining of the cavities was performed.

Results: The leaves of U. molinae are hypostomatic, have a wavy surface and possess scattered hairs. Leaf anatomical features include dorsiventral mesophyll, two to three layers of palisade parenchyma with abundant chloroplasts, calcium oxalate crystals and internal phloem in vascular bundles. Schizogenous secretory cavities are present on the abaxial surface and are mainly located on the margins of the leaves. Histochemical tests of these cavities suggest the presence of lipophilic substances.

Conclusions: This is the first study of secretory cavities in Chilean Myrtaceae. In general, micromorphological and anatomical characters are similar to other species of the family. The present findings could provide valuable anatomical information for future research in South American Myrtaceae.
\end{abstract}

Keywords: Anatomy; Myrtaceae; Secretory cavities; SEM; Terpenoids

\section{Background}

Myrtaceae Juss. (Myrtales; Angiosperm Phylogeny Group 2009) is a large family of angiosperms including approximately 5,500 species, divided into two subfamilies, 17 tribes and ca. 140 genera (Wilson et al. 2005; Biffin et al. 2010). It is a predominantly southern hemisphere family with a high diversity in South America and Australasia (Snow 2000). The genus Ugni Turcz. comprises four species distributed in South America from the Andean region from Chile to Mexico (Wilson 2011). Ugni molinae Turcz. (Myrtaceae) is a South American shrub that occurs in the humid temperate forests of south-central Chile and Argentina (Figure 1A) (Landrum 1988). The species is known as 'murta','murtilla' or 'Chilean guava' due to its edible fruits (Aguirre et al. 2006). Other commercial products include tea, essential

\footnotetext{
* Correspondence: hernanalfonso.retamales@student.qut.edu.au ${ }^{1}$ School of Earth, Environmental and Biological Sciences, Science and Engineering Faculty, Queensland University of Technology, Brisbane, QLD 4001, Australia

Full list of author information is available at the end of the article
}

oils and alcoholic extracts (Landrum 1988; Quilaqueo et al. 2012). The leaves and fruits of $U$. molinae are rich in antioxidants and phytoestrogenic substances that are used to treat digestive disorders, inflammations, urinary infections and diabetes (Rubilar et al. 2011; Avello et al. 2013). A number of studies have investigated the chemical compounds and the biochemical activity in the leaves of $U$. molinae, identifying polyphenols (condensed tannins), terpenoids, flavonoids and nanocomposite films of carboxymethylcellulose (Aguirre et al. 2006; Rubilar et al. 2006; Avello et al. 2013; Doll et al. 2012; Quilaqueo et al. 2012).

The other three species of Ugni, namely, Ugni candollei (continental Chile), Ugni selkirkii (Juan Fernandez Archipelago) and Ugni myricoides (Mexico, Central America to Bolivia), are not considered equally important in economic terms as $U$. molinae (Wilson 2011).

Secretory cavities are a common feature in Myrtaceae (Metcalfe and Chalk 1979), but there are a few studies regarding the anatomy of these structures in the family. Chemicals produced by secretory cavities also need more 

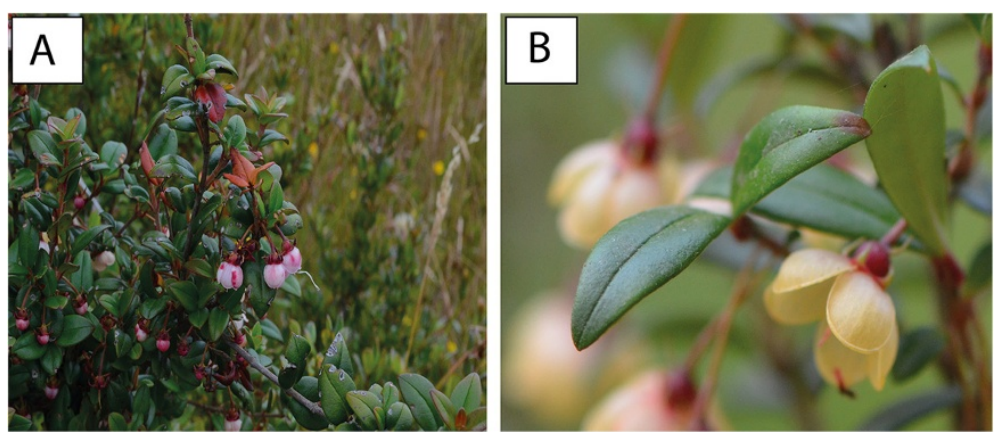

Figure 1 Ugni molinae, habit and leaf morphology. (A) Shrub. (B) Leaves.

investigation, as not many genera have been anatomically described (P.G. Wilson, pers. comm.). Similarly, development of secretory cavities in Myrtaceae has been scarcely investigated (Ciccarelli et al. 2003). Although the leaf chemistry of $U$. molinae has been comprehensively studied, there is no information regarding its leaf anatomy and micromorphology. Since the leaf anatomy is unknown, anatomical structure and development of secretory cavities in the species remain without clarification. The aims of this paper are (1) to describe the surface micromorphology and internal anatomy of the leaves of $U$. molinae for the first time and (2) to investigate the anatomical structure of secretory cavities in early and mature stages.

\section{Methods}

\section{Sampling}

Fresh leaf material was collected from natural populations in Chile. Mature leaves were collected randomly from sunexposed branches in different individuals from Futrono, Región de los Ríos (40 7' 28" S/72 22' 51" W) and Talcahuano, Región del Bio-Bio ( $\left.36^{\circ} 43^{\prime} 0^{\prime \prime} \mathrm{S} / 73^{\circ} 7^{\prime} 0^{\prime \prime} \mathrm{W}\right)$. Young leaves were also collected as trichomes, or certain structures are reported to be early caduceus (Landrum 1988). Fresh leaves were fixed in FAA for 24 to $48 \mathrm{~h}$. Specimens (Reta-04.1, Reta-04.2, Reta-04.3 and Reta-04.4) are currently housed at the Queensland Herbarium (BRI), Brisbane, Australia. Duplicates (Reta-04.5, Reta-04.6) are housed at EIF (Forestry Sciences, Universidad de Chile).

\section{Scanning electron microscopy}

Fixed leaf material was dehydrated using a graded ethanol series and then critical point dried (Anderson 1951) in an Autosamdri-815 automatic critical point drier (Tousimis, Rockville, USA). Samples were mounted on stubs with self-adhesive double-sided carbon discs and sputter coated with gold palladium for $175 \mathrm{~s}$ using a Leica EM SCD005 gold coater (Leica Microsystems, Wetzlar, Germany). Examination and photography were conducted using a FEI
Quanta 200 scanning electron microscopy (SEM)/ESEM (FEI, Hillsboro, OR, USA) operated at $10 \mathrm{kV}$.

\section{Light microscopy}

Fixed material was dehydrated through a graded ethanol series, infiltrated and embedded in paraffin wax (Johansen 1940; Ruzin 1999). Transverse sections were cut using a Leica RM2245 rotary microtome at $5 \mu \mathrm{m}$ and placed onto microscope slides. The sections were stained using a $0.05 \%$ $(w / v)$ of ruthenium red in distilled water for $2 \mathrm{~min}$ and counterstained with a $0.1 \%$ solution $(w / v)$ of toluidine blue (TBO) in distilled water for $45 \mathrm{~s}$. The sections were dehydrated post-staining through a graded ethanol series and mounted using Depex (Depex Colour Lab Ltd., Roseau, Dominica). Additional histochemical tests were performed using freehand sections of fixed leaves (Cutler et al. 2008) stained with phloroglucinol- $\mathrm{HCl}$, Sudan IV and IKI to test the composition of secreted chemicals if secretory cavities are present in the species. Leaf clearings were prepared by immersing tissue fragments of 1 to $2 \mathrm{~cm}^{2}$ in $10 \% \mathrm{KOH}$ at room temperature for $48 \mathrm{~h}$ followed by $7 \% \mathrm{NaClO}$ for $2 \mathrm{~h}$ or until the leaves turned transparent. Cleared leaves were washed five times with distilled water, stained with Safranin $\mathrm{O} / \mathrm{TBO}$ and mounted with lactoglycerol (lactic acidglycerol 1:1). Slides were observed using a Nikon SMZ800 stereo light microscope (Nikon Eclipse 50i compound, Nikon Corporation, Tokyo, Japan) and images captured using the Nikon NIS-Elements imaging software.

\section{Terminology}

Terminology for describing the Myrtaceae leaf micromorphology was based on previous descriptions in van Wyk et al. (1982), Fontenelle et al. (1994) and Haron and Moore (1996). Terminology for leaf anatomy was based on Schmid (1980), Schmid and Baas (1984), Keating (1984), Cardoso et al. (2009) and Soh and Parnell (2011). Other general references consulted for anatomical terminology were Esau (1953), Gifford and Foster (1989), Dickison (2000) and Cutler et al. (2008). 


\section{Results \\ Leaf overview}

The leaves of $U$. molinae are simple, opposite and lanceolata, elliptic or ovate in shape. The apex is acuminate and the base acute to rounded. The blades have a rough and uneven appearance on the adaxial surface (Figure 1B). The leaves are dorsiventral and have a noticeable depression directly above the midrib (Figure 2A). The leaves have numerous secondary and tertiary reticulate veins. Venation is pinnate and weakly to strongly brochidodromus (Figure 2B). Venation is barely visible externally.

\section{Cuticle, epidermal cells and stomata}

The adaxial surface has a prominent cuticle, which probably contains polyphenols due to bluish-green staining with
TBO. On this surface, the cuticle has a wavy and undulate deposition and might be the reason for the rough appearance of the leaves (Figure 2C). Adaxial and abaxial epidermal cells are compressed, plano-convex, mainly isodiametric and containing abundant tannins (Figure 2C). In paradermal view, adaxial epidermal cells have straight cell walls and are very compressed, while abaxial epidermal cells are irregularly rounded and the anticlinal cell walls are strongly sinuous (Figure 2D). The leaves of $U$. molinae are hypostomatic and stomatal complexes are anomocytic (Figure 2D). The stomata are circular to elliptical and are located at the same level as the epidermal cells. The dimension of stomata is 10 to $15 \mu \mathrm{m}$ long. Guard cells are kidney shaped, and the cell lumen between them is narrow at the equatorial region. Guard cells have cutinized
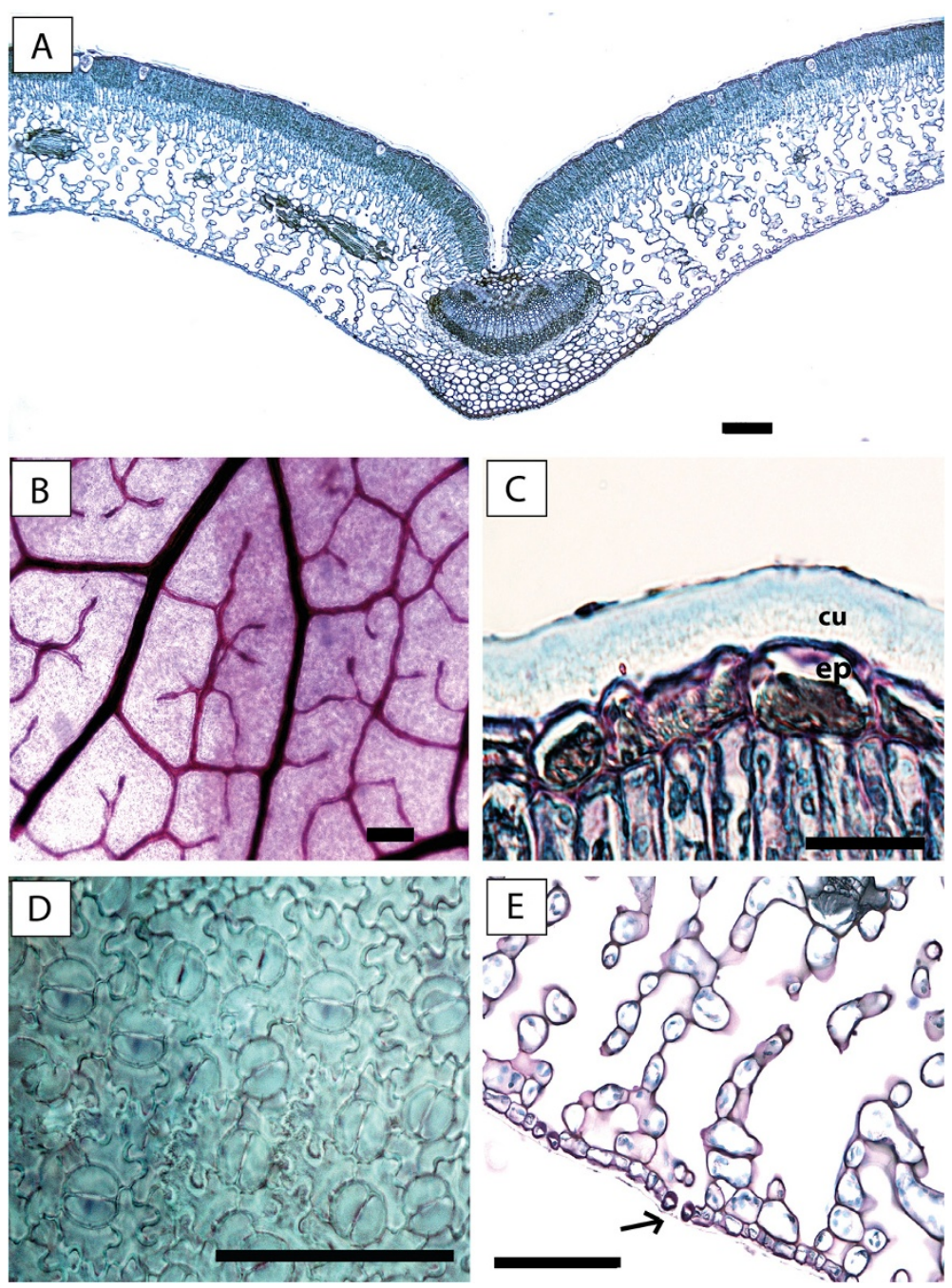

Figure 2 Light micrographs (LM) of the leaves of U. molinae. (A) Anatomical overview of the leaf blade. (B) Leaf clearing showing reticulate tertiary venation. (C) Epidermal cells and cuticle. (D) Leaf clearing showing sinuous epidermal cells and anomocytic stomata on the abaxial surface. (E) Transverse section of the mesophyll showing stomata with cutinized outer periclinal walls of guard cells and stomatal chamber connected to the spongy parenchyma. cu, cuticle; ep, epidermal cells. Arrow: stomata. Scale bars $=100 \mu \mathrm{m}$. 
thickenings on the outer periclinal walls, which are more visible in cross section (Figure 2E). Stomata are regularly distributed on the surface of the leaf (Figure 3A).

\section{Trichomes}

The adaxial surface of the leaves is glabrous (Figure 3B), while abaxially, it has some scattered hairs, which are sparsely strigose on the midrib. Hairs are simple, unicellular, non-glandular, solitary, conical and slightly wavy. Both deciduous and persistent hairs are present (Figure 3C). Bases of deciduous trichomes are abundant on the midrib of the abaxial surface.

\section{Midrib}

The midrib is strongly impressed on the adaxial surface (Figures $1 \mathrm{~B}$ and $3 \mathrm{~B}$ ) and slightly prominent below. There is a notorious depression on the adaxial surface above the midrib. This species has an internal phloem as in other Myrtaceae. The midrib is arc shaped with a strong curvature (Figure 4A). There is a strongly developed adaxial phloem partition. Incurved margins of the phloem are well developed. Adaxial and abaxial phloems are not confluent. Fibres are discontinuous around the midrib. Xylem vessels of the midrib show scalariform perforation plates and helical wall thickenings. Phloem sieve tubes and companion cells have thin primary cell walls. Phloem fibres have evident and thick secondary cell walls.
An extension of the bundle sheath, composed of rounded-polygonal cells, is clearly visible under the midrib and slightly developed above.

\section{Mesophyll}

The mesophyll is formed by a three- to four-layered palisade parenchyma and a spongy parenchyma with abundant intercellular spaces (Figure 2A). The palisade parenchyma layer is somewhat dense and composed of rectangular, attenuated and vertical cells. These cells possess thin primary cell walls and numerous chloroplasts. The spongy parenchyma is composed of irregularly shaped cells (rounded to star shaped). Both palisade and spongy parenchyma contain mucilage. Subepidermal idioblasts with calcium oxalate crystals (druses) occur throughout the palisade parenchyma (Figure 4B).

\section{Secretory cavities}

Leaf secretory cavities are exclusively located under the abaxial epidermis of the leaves and in some cases as part of this layer. The cavities are slightly visible above the epidermis level and form a pronounced swelling (Figure 3D). Secretory cavities are composed of large spaces surrounded by a sheath of peripheral epithelial cells, which are almost disintegrated in mature leaves. These structures are particularly close to the margin of the leaves (Figure 4C). The presence of epithelial cells surrounding a cavity space demonstrates the schizogenous development of the cavities
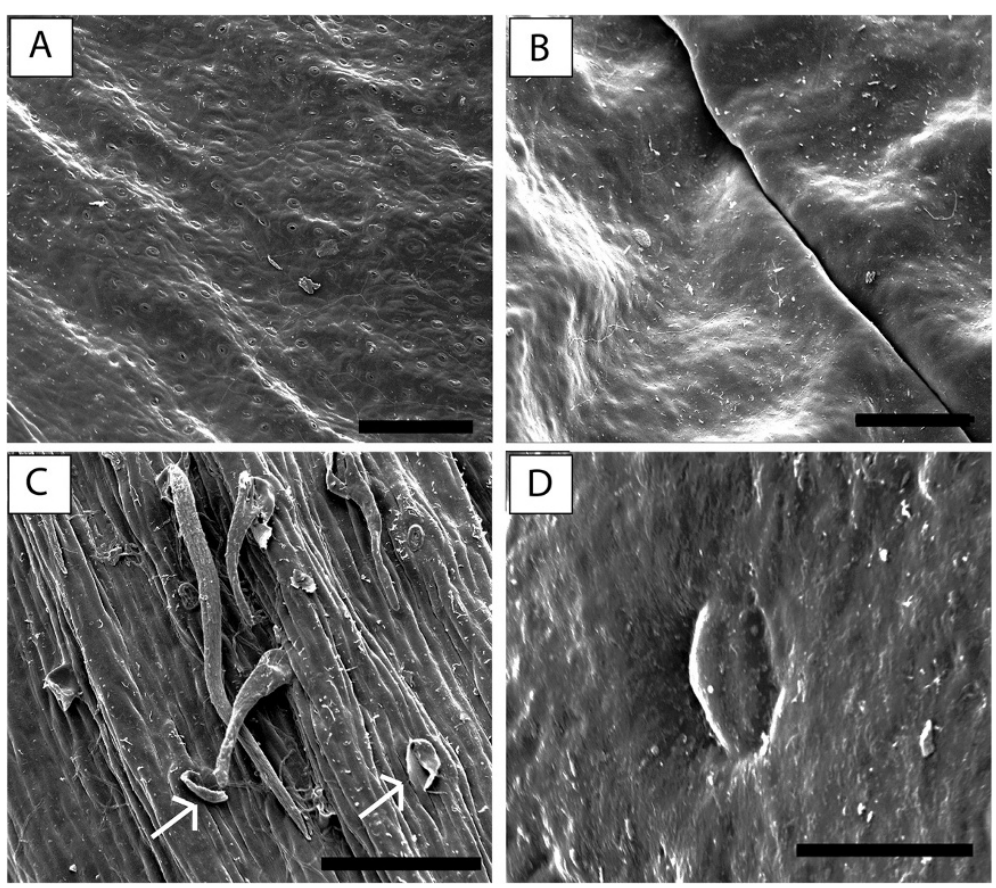

Figure 3 Scanning electron micrographs (SEM) of the leaves of U. molinae. (A) Abaxial surface showing stomatal distribution. (B) Adaxial surface showing impressed midrib and glabrescent wavy surface. (C) Unicellular hairs and bases of deciduous trichomes on the abaxial midrib (arrows). (D) SEM micrograph of subepidermal secretory cavity, visible as a pronounced swelling. Scale bars $=100 \mu \mathrm{m}$ (A, B) and $50 \mu \mathrm{m}$ (C, D). 


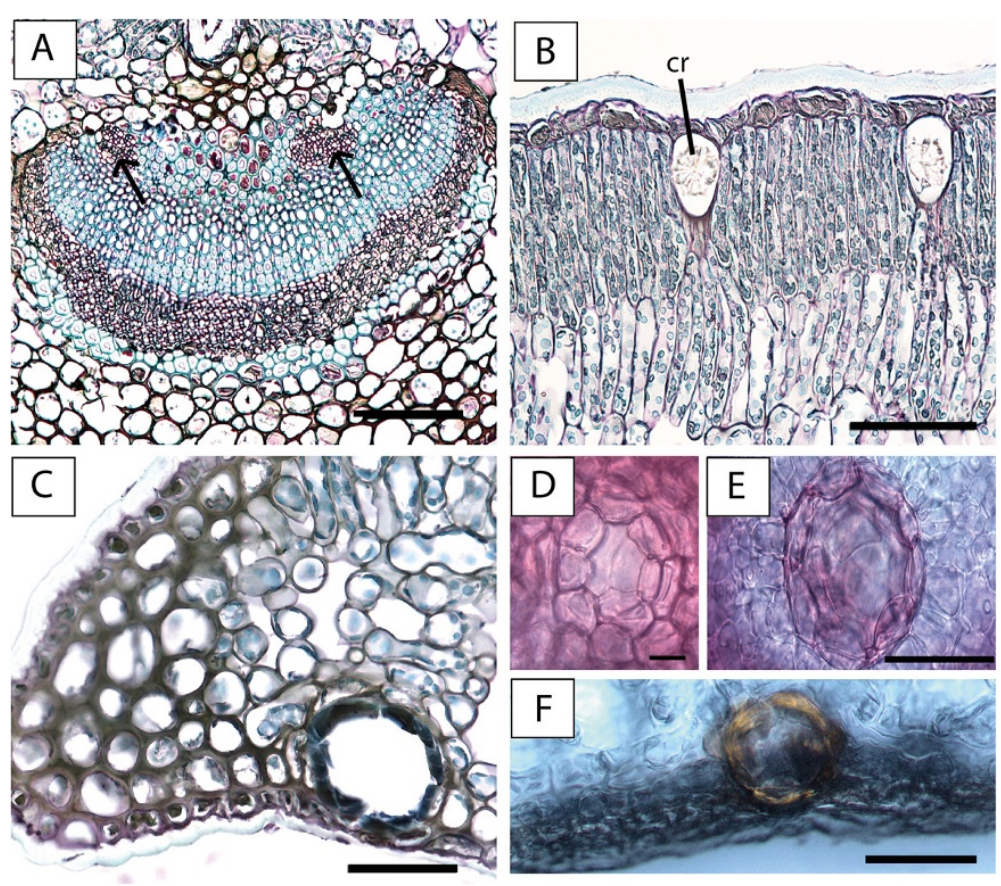

Figure 4 Light micrographs (LM) showing midrib, mesophyll and secretory cavities of U. molinae. (A) Detail of midrib showing developed adaxial phloem partition, incurved margins of the phloem and discontinuous fibres. (B) Transverse section of the leaf showing cells with idioblasts containing druses (calcium oxalate crystals) below the epidermis. (C) Transverse section of the leaf showing a secretory cavity and epithelial cells on the abaxial surface close to the leaf margin. (D) Early developmental stage of secretory cavity showing epithelial cells in formation. (E) Secretory cavity with eight epithelial cells in formation in young leaves. (F) Freehand section showing secretory cavity on the abaxial side of the leaf. Histochemical reaction indicates lipophilic compounds in the epithelial cells after testing with Sudan IV (orange colour). cr, crystals (druses). Arrows: internal phloem. Scale bars $=100 \mu \mathrm{m}(\mathbf{A}-\mathbf{C}, \mathbf{E}-\mathbf{F})$ and $10 \mu \mathrm{m}$ (D)

for separation of cells and not dissolution as the lysigenous type. Epithelial cells are initially developed from the protodermis and ground meristem as shown in leaf primordia (Figure 4D). These cells are small ( $12 \pm 4 \mu \mathrm{m}$ in diameter), compressed and have very thin cell walls. The final numbers of epithelial cells are reached quickly after the first periclinal divisions in the meristem. During leaf expansion and differentiation, secretory cavities increase their size and the area of the cavity becomes larger (Figure 4D,E). In mature leaves, these structures are abundant throughout the mesophyll and have variable dimensions $(75 \pm 35 \mu \mathrm{m}$ in diameter). Histochemical reaction with Sudan IV reveals the presence of lipophilic substances in the epithelial cells (Figure 4D). This was the only positive reaction among the performed histochemical tests.

\section{Discussion}

Even though species of Myrtaceae are rich in essential oils and other chemical compounds, information concerning leaf anatomy and histochemistry is scarce. $U$. molinae is one of the most studied species of South American Myrtaceae, but mainly regarding chemical composition. Results of this investigation show that $U$. molinae shares a number of anatomical traits with other species of the family. These characters include druses (calcium oxalate crystals), adaxial phloem and secretory cavities. Calcium oxalate crystals are abundant in the leaves of $U$. molinae, especially in the palisade parenchyma, just below the adaxial epidermis. Druses are widely present in several genera of Myrtaceae, in diverse vegetative and reproductive structures. Donato and Morretes (2007, 2009) and Alves et al. (2008) described druses of calcium oxalate in South American species of Eugenia. Donato and Morretes (2011) reported the same structures for Myrcia multiflora. Polyhedral crystals, including druses, have been reported in Psidium, Eugenia, Gomidesia and Myrcia, among others (Cardoso et al. 2009; Gomes et al. 2009). The function of these structures is not completely clear but has been related to the regulation of calcium and other minerals (Volk et al. 2002), as well as protection against herbivores and pathogens (Franceschi and Nakata 2005; Korth et al. 2006). The habitat preference of $U$. molinae supports this hypothesis, because the species normally occurs in calcium-rich soils and is severely attacked by insects (Kausel 1947; Navas 1970).

Internal phloem was found in midribs, either as continuous tissue or strands in the adaxial side of the midrib. This character is regarded as a typical anatomical character in the order Myrtales (Cronquist 1981; Takhtajan 1980) and is widely present in Myrtaceae (Schmid 1980; Cardoso 
et al. 2009). The development of the adaxial phloem and the confluence between adaxial and abaxial phloem and continuity of fibres around midrib are regarded as suitable characters to identify species in Myrtaceae (Cardoso et al. 2009; Soh and Parnell 2011).

Helical wall thickenings on vessel elements of the xylem tissue have been reported in a number of Myrtaceae genera, such as Myrceugenia, Myrtus, Austromyrtus, Myrcia, Myrcianthes and Psidium (Schmid and Baas 1984). Similarly, scalariform perforation plates on vessels have been identified in Myrceugenia, Luma, Tepualia, Ugni, Neomyrtus and Myrtastrum (Schmid and Baas 1984). Helical wall thickenings of vessels and scalariform perforation plates as observed in $U$. molinae have been attributed to putatively primitive species (Stern 1978), the latter possibly as an adaptation of a common ancestor to cooler or mountain environments (Jansen et al. 2004).

The secretory cavities follow the typical schizogenous pattern commonly observed in Myrtaceae (Alves et al. 2008; Donato and Morretes 2007; Gomes et al. 2009). The observation of undifferentiated epithelial cells in leaf primordia and developed ones in mature leaves confirms this pattern. Similarly, Cicarelli et al. (2003, 2008) describe this type of initial development of secretory cavities in Myrtus communis. These authors report that the ontogeny of secretory cavities in M. communis follows a schizolysigenous development, which is a combination of lysigenous (due to disintegration of cells) and schizogenous. The origin of schizogeneous cavities in Myrtaceae has been suggested from protoderm or epidermal meristems, with the participation of the ground meristem (Arruda and Fontenelle 1994; Fahn 1979). In U. molinae, the origin has been identified from both of these tissues. Secretory cavities are produced by periclinal divisions of these meristems, which produce sets of internal and external cells. Internal cells produce the epithelial cells of the cavities, while the more external remain as epidermal cells. The development of secretory cavities matches with the descriptions of Fahn (1979).

The main chemical compounds identified in the leaves of South American Myrtaceae include cyclic sesquiterpenes and monoterpenes in Blepharocalyx (Godinho et al. 2014), Eugenia, Myrcia and Psidium (Stefanello et al. 2011). Other compounds are flavonoids (Wollenweber et al. 2000), tannins (Tanaka et al. 1996) and triterpenoids (Lee 1998; Judd et al. 1999). Triterpenoids are widely present in many families of plants and are produced in different parts of the leaves, not only in secretory cavities (Xiao et al. 2008). Histochemical test with Sudan IV suggests that secretory cavities of $U$. molinae produce mainly lipophilic compounds, similar to those identified in South American Myrtaceae. Other tests with phloroglucinol- $\mathrm{HCl}$ and IKI were negative in secretory cavities.
Monoterpenes, among most members such as $\alpha$ - and $\beta$ pinene, 1,8-cineole, limonene, sabinene, terpinen-4-ol and $\alpha$-terpineol, have been detected in several species of Myrtaceae (Shellie et al. 2004; Stefanello et al. 2011; Victorio et al. 2011). Secretory cavities in Myrrhinium atropurpureum have been confirmed as producers of these compounds (Victorio et al. 2011). The role of terpenoids and monoterpenes has been associated to a number of plant functions. These roles are related to direct defense responses (Cheng et al. 2007), metabolism of diverse chemicals (Banthorpe et al. 1972), plant-environment interactions (Lange and Ahkami 2013) and plant architecture, through inhibition of shoot branching (Akiyama et al. 2008).

\section{Conclusions}

In this paper, the foliar micromorphology and anatomy of $U$. molinae have been described for the first time. Schizogenous secretory cavities are abundant in the leaves and produce mainly lipophilic compounds, according to histochemical staining. This is the first report regarding the anatomical structure, development and histochemistry of secretory cavities in the species. The species shares a number of anatomical and micromorphological characters with other Myrtaceae. Results from this investigation are potentially useful for future anatomical studies in South American Myrtaceae.

\section{Competing interests}

The authors declare that they have no competing interests.

\section{Authors' contributions}

HR conceived the study, carried out the anatomical and micromorphological analyses and drafted the manuscript. RS helped with the sampling strategy and academic input in the early stages of this project and also provided laboratory supplies for field work. TS was responsible for important academic input for the study, including experimental design and editing of the manuscript. All authors read and approved the final manuscript.

\section{Acknowledgements}

This work was funded by CONICYT-Government of Chile. The authors are very thankful to Helen O'Connor, Rachel Hancock and Amy Carmichael (QUT) for helping with the embedding, sectioning and image acquisition, respectively. Thanks to the Plant Structure and Systematics group (QUT) for the advice and feedback. We appreciate the valuable feedback from an anonymous reviewer.

\section{Author details}

${ }^{1}$ School of Earth, Environmental and Biological Sciences, Science and Engineering Faculty, Queensland University of Technology, Brisbane, QLD 4001, Australia. ${ }^{2}$ Plant Biology Laboratory, Faculty of Forest Sciences and Nature Conservation, University of Chile, P.O. Box 9206, Santiago, Chile.

Received: 9 September 2014 Accepted: 4 November 2014 Published online: 18 November 2014

\section{References}

Aguirre MC, Delporte C, Backhouse N, Erazo S, Letelier ME, Cassels B, Silva X, Alegría S, Negrete R (2006) Topical anti-inflammatory activity of 2a-hydroxy pentacyclic triterpene acids from the leaves of Ugni molinae. Bioorg Med Chem 14:5673-5677

Akiyama K, Arite T, Hanada A, Kamiva Y, kyouza J, Magome H (2008) Inhibition of shoot branching by new terpenoid plant hormones. Nature 455:195

Alves E, Tresmondi F, Longui E (2008) Análise estrutural de folhas de Eugenia uniflora L. (Myrtaceae) coletadas em ambientes rural e urbano, SP, Brasil. Acta Botanica Brasilica 22(1):241-248 
Anderson T (1951) Techniques for the preservation of three-dimensional structure in preparing specimens for the electron microscope. Trans N Y Acad Sci 13:130

Angiosperm Phylogeny Group (2009) An update of the Angiosperm Phylogeny Group classification for the orders and families of flowering plants: APG III. Bot J Linnean Soc 161:105-121

Arruda RCO, Fontenelle GB (1994) Anatomia foliar de Psdium cattleyanum. Res Bras de Bot 17:25-35

Avello MA, Pastene ER, Bustos ED, Bittner ML, Becerra JA (2013) Variation in phenolic compounds of Ugni molinae populations and their potential use as antioxidant supplement. Brazilian J Pharmacognosy 23(1):44-50

Banthorpe DV, Charlwood BV, Francis MJO (1972) The biosynthesis of monoterpenes. Chem Rev 72:115-149

Biffin E, Lucas E, Craven L, Ribeiro da Costa I, Harrington M, Crisp M (2010) Evolution of exceptional species richness among lineages of fleshy-fruited Myrtaceae. Ann Bot 106:79-93

Cardoso CMV, Proença SL, Sajo MG (2009) Foliar anatomy of the subfamily Myrtoideae (Myrtaceae). Aust J Botany 57(2):148-161

Cheng A, Lou YG, Mao YB, Lu S, Wang LJ, Chen XY (2007) Plant terpenoids: biosynthesis and ecological functions. J Integr Plant Biol 49(2):179-186

Ciccarelli D, Pagni AM, Andreucci AC (2003) Ontogeny of secretory cavities in vegetative parts of Myrtus communis L. (Myrtaceae): an example of schizolysigenous development. Israel J Plant Sci 51:193-198

Ciccarelli D, Garbari F, Pagni AM (2008) The flower of Myrtus communis (Myrtaceae): secretory structures, unicellular papillae, and their ecological role. Flora Morphology, Distribution, Functional Ecology of Plants 203(1):85-93

Cronquist A (1981) An integrated system of classification of flowering plants. Columbia University Press, New York

Cutler DF, Botha T, Stevenson DW (2008) Plant anatomy: an applied approach. Oxford Blackwell Publishing, London

Dickison W (2000) Integrative plant anatomy. Harcourt Academic Press, San Diego

Doll U, Rodriguez I, Soto C, Razmilic I (2012) Cutting propagation and tannin and flavonoid concentration in leaves of two Ugni molinae provenances from the Maule Region (Chile). Bosque 33(2):203-209. doi:10.4067/S0717 92002012000200010

Donato AM, Morretes BL (2007) Anatomia foliar de Eugenia brasiliensis Lam. (Myrtaceae) proveniente de áreas de restinga e de floresta. Revista Brasileira de Farmacognosia 17:426-443

Donato AM, Morretes BL (2009) Anatomia foliar de Eugenia florida DC. (Myrtaceae). Rev Bras de Farmacognosia 19:759-770

Donato A, Morretes B (2011) Leaf morphoanatomy of Myrcia multiflora (Lam.) DC. - Myrtaceae. Rev Bras de Plantas Med 13(1):43-51

Esau K (1953) Plant anatomy. John Wiley and Sons Inc, New York

Fahn A (1979) Secretory tissues in plants. Academy Press, London

Fontenelle GB, Costa CG, Machado RD (1994) Foliar anatomy and micromorphology of eleven species of Eugenia L. (Myrtaceae). Bot J Linnean Soc 116(2):111-133

Franceschi V, Nakata P (2005) Calcium oxalate in plants: formation and function. Annu Rev Plant Biol 56:41-71

Gifford E, Foster A (1989) Morphology and evolution of vascular plants, 3rd edition. Freeman, New York

Godinho W, Farnez M, Pereira I, Regorio L, Grael C (2014) Volatile constituents from leaves of Blepharocalyx salicifolius (Kunth) O.Berg (Myrtaceae). Boletín Latinoamericano y del Caribe de Plantas Medicinales y Aromáticas 13(3):249-253

Gomes SM, Somavilla N, Gomes-Bezerra KM, Miranda S, De-Carvalho PS, Graciano-Ribeiro D (2009) Anatomia foliar de espécies de Myrtaceae: contribuições à taxonomia e filogenia. Acta Bot Bras 23(1):223-238

Haron NW, Moore DM (1996) The taxonomic significance of leaf micromorphology in the genus Eugenia L. (Myrtaceae). Bot J Linnean Soc 120:265-277

Jansen S, Baas P, Gasson P, Lens F, Smets E (2004) Variation in xylem structure from tropics to tundra: evidence from vestured pits. Proc Natl Acad Sci U S A 101:8833-8837

Johansen DA (1940) Plant microtechnique. Mc Graw Hill, London

Judd W, Campbell CS, Kellogg EA, Stevens PF (1999) Plant systematics: a phylogenetic approach. Sinauer Associates, Sunderland

Kausel E (1947) Notas mirtológicas. Lilloa 11(4):320-327

Keating RC (1984) Leaf histology and its contribution to relationships in the Myrtales. Ann Mo Bot Gard 71:801-823

Korth K, Doege S, Park S, Goggin F, Wang Q, Gomez S, Liu G, Jia L, Nakata P (2006) Medicago truncatula mutants demonstrate the role of plant calcium oxalate crystals as an effective defense against chewing insects. Plant Physiol 141:188-195

Landrum LR (1988) The myrtle family (Myrtaceae) in Chile. Proc Calif Academy Sci 45:277-317

Lange BM, Ahkami A (2013) Metabolic engineering of plant monoterpenes, sesquiterpenes and diterpenes - current status and future opportunities. Plant Biotechnol J 11:169-196

Lee C (1998) Ursane triterpenoids from leaves of Melaleuca leucadendron. Phytochemistry 49:1119-1122

Metcalfe C, Chalk L (1979) Anatomy of the dicotyledons. Clarendron Press, Oxford

Navas E (1970) Distribución geográfica de las Mirtáceas Chilenas. Boletín del Museo Nacional de Historia Natural 29:223-247

Quilaqueo M, Echeverria I, Ihl M, Bifani V, Mauri A (2012) Carboxymethylcellulosemontmorillonite nanocomposite films activated with murta (Ugni molinae Turcz.) leaves extract. Carbohydr Polym 87:1495-1502

Rubilar M, Pinelo M, Ihl M, Schuermann E, Sineiro J, Nuñez MJ (2006) Murta leaves (Ugni molinae Turcz.) as a source of antioxidant polyphenols. J Agric Food Chem 54(59-64):59

Rubilar M, Jara C, Poo Y, Acevedo F, Gutierrez C, Sineiro J, Shene C (2011) Extracts of maqui (Aristotelia chilensis) and murta (Ugni molinae Turcz.): sources of antioxidant compounds and a-glucosidase/a-amylase inhibitors. J Agric Food Chem 59:1630-1637. dx.doi.org/10.1021/jf103461k

Ruzin SE (1999) Plant microtechnique and microscopy. Oxford University Press, New York

Schmid R (1980) Comparative anatomy and morphology of Psiloxylon and Heteropyxis, and the subfamilial and tribal classification of Myrtaceae. Taxon 29(5/6):559-595

Schmid R, Baas P (1984) The occurrence of scalariform perforation plates and helical vessel wall thickenings in wood of Myrtaceae. IAWA Bulletin 5:197-215

Shellie R, Mondello L, Dugo G, Marriott P (2004) Enantioselective gas chromatographic analysis of monoterpenes in essential oils of the family Myrtaceae. Flavour and Fragrance J 19(6):582-585

Snow N (2000) Systematic conspectus of Australasian Myrtinae (Myrtaceae) Kew Bulletin 55:647-654

Soh W, Parnell J (2011) Comparative leaf anatomy and phylogeny of Syzygium Gaertn. Plant Systematics and Evolution 297(1-2):1-32

Stefanello M, Pascoal A, Salvador M (2011) Essential oils from neotropical Myrtaceae: chemical diversity and biological properties. Chem Biodivers 8:73-94

Stern W (1978) A retrospective view of comparative anatomy, phylogeny, and plant taxonomy. IAWA Bulletin 2:33-39

Takhtajan AL (1980) Outline of the classification of flowering plants (magnoliophyta). The Bot Rev 46(3):225-359

Tanaka T, Orii Y, Nonaka G, Nishioka I, Kuono I (1996) Syzyginins A and B, two ellagitannins from Syzygium aromaticum. Phytochemistry 43:1345-1348

Van Wyk A, Robbertse PJ, Kok P (1982) The genus Eugenia L. (Myrtaceae) in southern Africa: the structure and taxonomic value of stomata. Bot J Linnean Soc 84:41-56

Victorio CP, Moreira CB, Souza MD, Sato A (2011) Secretory cavities and volatiles of Myrrhinium atropurpureum Schott var. atropurpureum (Myrtaceae): an endemic species collected in the restingas of Rio de Janeiro, Brazil. Nat Prod Commun 6(7):1045-1050

Volk G, Lynch-Holm V, Kostman T, Goss L, Franceschi V (2002) The role of druse and raphide calcium oxalate crystals in tissue calcium regulation in Pistia stratiotes leaves. Plant Biology 4:34-45

Wilson P, O'Brien M, Heslewood M, Quinn C (2005) Relationships within Myrtaceae sensu lato based on a matK phylogeny. Plant Syst Evol 251:3-19

Wilson P (2011) Myrtaceae. In: Kubitzki K (ed) The families and genera of vascular plants. Vol. X. Flowering plants Eudicots: Sapindales, Cucurbitales, Myrtaceae. Springer-Verlag, Heidelberg, pp 212-271

Wollenweber E, Wehde R, Dörr M, Lang G, Stevens J (2000) C-Methyl-flavonoids from the leaf waxes of some Myrtaceae. Phytochemistry 55:965-970

Xiao W, Li R, Huang S, Pu J, Sun H (2008) Triterpenoids from the Schisandraceae family. Nat Prod Rep 25(5):871-891. dx.doi.org/10.1039/b719905h

\section{doi:10.1186/s40693-014-0027-x}

Cite this article as: Retamales et al:: Foliar micromorphology and anatomy of Ugni molinae Turcz. (Myrtaceae), with particular reference to schizogenous secretory cavities. Revista Chilena de Historia Natural $201487: 27$ 